\title{
THE USE OF $\mathrm{K}^{42}$ OR $\mathrm{P}^{82}$ LABELED ERYTHROCYTES AND I ${ }^{181}$ \\ TAGGED HUMAN SERUM ALBUMIN IN SIMULTANEOUS BLOOD VOLUME DETERMINATIONS ${ }^{1}$
}

\author{
By SOLOMON A. BERSON AND ROSALYN S. YALOW
}

(From the Radioisotope Unit of the Veterans Administration Hospital, Bronx, N. Y.)

(Submitted for publication February 9, 1952; accepted March 31, 1952)

Recent methods of measuring the volume of the circulating blood have employed the dilution principle, using either labeled red blood cells or substances which presumably travel with the plasma. Earlier methods made use of carbon monoxide (1) or specific agglutinogens (2) by the Ashby technique (3) as specific erythrocyte labels. In the past few years a variety of radioisotopes, $\mathrm{Fe}^{58}, \mathrm{Fe}^{50}$ $(4,5), \mathrm{Cr}^{51}(6), \mathrm{P}^{32}(7)$, and $\mathrm{K}^{42}(8)$, have been found useful for this purpose. The most commonly employed plasma soluble substance has been Evans blue dye, T-1824 (9), its successful usefulness depending on its presumed rapid and complete binding to the circulating albumin (10). Recently plasma proteins tagged with $\mathrm{I}^{181}$ have been used in the determination of blood volume (11-13).

In a number of reports $(3,5,14-18)$ simultaneous studies have yielded higher values for total blood volume by the dye method than by tagged erythrocyte methods. This finding led to the conclusion that the average body hematocrit is lower than the peripheral vessel hematocrit. Offered in support of this concept is the observation that postphlebotomy red blood cell volumes calculated from the dye plasma volume and the hematocrit appeared lower than predicted from the pre-hemorrhage red cell value and the volume of red cells removed (19).

A contradictory opinion was presented by Gregersen (20) who found that blood volumes calculated from T-1824 dye dilution and the $\mathrm{CO}$ tagged red blood cell method gave values in satisfactory agreement and by Noble and Gregersen (21) who

\footnotetext{
1 Reviewed in the Veterans Administration and published with the approval of the Chief Medical Director. The statements and conclusions published by the authors are the results of their own study and do not necessarily reflect the opinion or policy of the Veterans Administration.
}

found that the increase in red blood cell volume after transfusion as determined from the dye plasma volume and hematocrit agreed well with the quantity of cells given in transfusion. Hopper, Tabor, and Winkler (22) also obtained almost identical results for average blood volume values calculated from T-1824 and CO tagged red blood cell dilution but concluded that neither method had been shown regularly to measure blood volume. Subsequently, Nickerson, Sharpe, Root, Fleming, and Gregersen (23) found that the radioactive iron $\left(\mathrm{Fe}^{\mathrm{s5}}\right)$ tagged erythrocyte method gave lower blood volumes than the T-1824 dye method.

A further disagreement was introduced by Mayerson, Lyons, Parson, Nieset, and Trautman (24) who found almost identical values in simultaneous studies utilizing Evans blue dye and $\mathrm{P}^{32}$ tagged red blood cells when they applied the $81 / 2 \%$ hematocrit correction factor of Chapin and Ross (25) for trapped plasma. Using the same correction factor they recalculated the data of Gibson, Peacock, Seligman, and Sack (5) and Meneely, Wells, and Hahn (17) and obtained similar values for total blood volume as determined by the tagged red blood cell and Evans blue methods. They concluded that the appearance of differences between average body hematocrit and the peripheral vessel hematocrit arises chiefly from neglect of correction for trapped plasma in the centrifuged hematocrit tube. However, two recent similar studies $(26,27)$ demonstrated such differences even when the same correction factor was applied.

The demonstration that Evans blue dye appears in lymph fluid shortly after injection (28) and that dye concentration in the blood stream decreases at a relatively rapid rate during the first few minutes (29) has led to questions concerning the validity of its use as a measure of plasma volume with the implication that loss from the intravascular circulation leads to a significant overestimation $(30,31)$. 
Crispell, Porter, and Nieset (13) found comparable results for plasma volumes obtained with Evans blue and with $\mathrm{I}^{181}$ tagged serum albumin. However, Storaasli, Krieger, Friedell, and Holden (12) found that the volume obtained with T-1824 was considerably greater than that with iodinated protein in all but one of 15 cases. On the other hand, simultaneous studies by this group of workers (11), using $\mathrm{P}^{32}$ tagged red blood cells and radio-iodinated serum protein in dogs, gave almost identical values. These latter results would imply that the higher blood volume values obtained with Evans blue as compared to tagged red blood cell methods are presumably in error due to overestimation by the former method.

In view of the contradictory evidence bearing on the relative validity of plasma soluble substances and tagged erythrocyte methods in blood volume determinations, it seemed advisable to reinvestigate this problem in a manner which would avoid points of previous dispute. In the present study simultaneous determinations of the blood volume of human subjects made with $\mathrm{I}^{\mathbf{1 8 1}}$ labeled albumin and with $\mathrm{P}^{32}$ or $\mathrm{K}^{42}$ tagged red blood cells have been compared and the problem of the average body hematocrit has been considered.

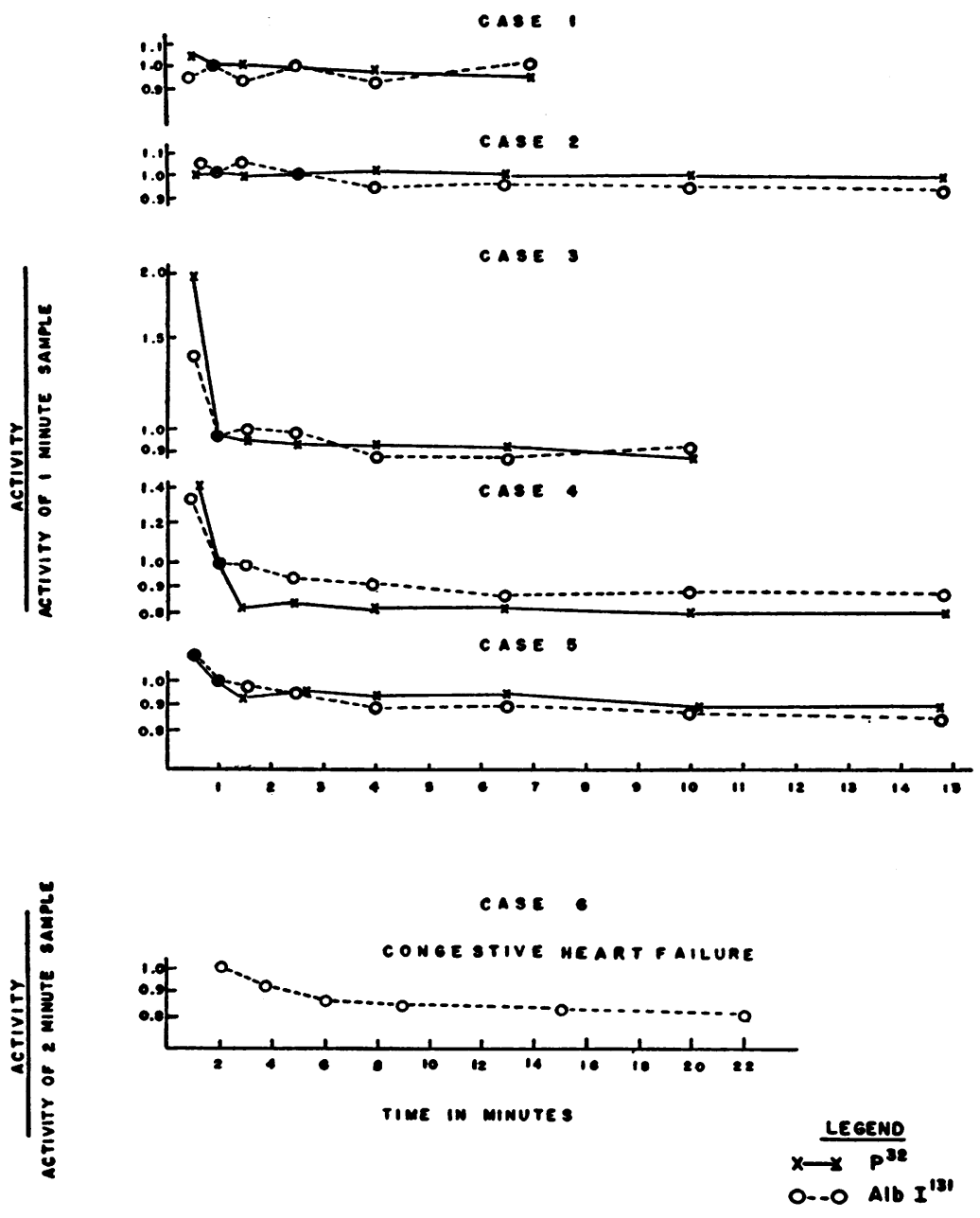

Fig. 1. Semilogarithmic Plot-Arterial Concentrations of Pe Tageed

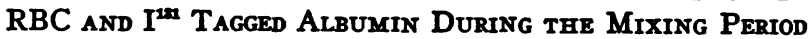

The concentrations are plotted relative to the one minute point in cases 1-5 and and to the two minute point in case 6. 
The influence of errors of the centrifuged hematocrit value on the ratio of the peripheral vessel hematocrit to average body hematocrit has been obviated by the assay of whole blood rather than of plasma or red blood cells.

\section{METHODS}

Subjects were hospitalized patients of the Veterans Administration Hospital, Bronx, New York, and all were kept at complete bed rest for a minimum of three hours prior to the studies.

The $\mathrm{K}^{20}$ and $\mathrm{P}^{\mathrm{s}}$ were obtained from Oak Ridge National Laboratory and were prepared for human use in neutral sterile isotonic saline solution. Ten $\mathrm{ml}$. of heparinized blood were incubated under sterile conditions in a rubber-stoppered centrifuge tube at $37^{\circ}$ for two hours with either $50 \mu \mathrm{c}$. carrier-free $\mathrm{P}^{23}$ or with $200 \mu \mathrm{c}$. $\mathrm{K}^{20}$ contained in $50 \mathrm{mg}$. stable potassium carrier. The plasma and buffy coat were removed. The labeled cells were then repeatedly centrifuged and washed with isotonic saline until the total activity in the final wash, performed no more than one-half hour prior to injection, was less than $1 \%$ of that activity bound to the red blood cells. Usually two to three washings were sufficient. The red blood cells were then prepared for injection by suspension in an equal volume of saline. Approximately $5 \mathrm{ml}$. of the suspension containing 7 to $12 \mu \mathrm{c}$. $\mathrm{P}^{\infty}$ or 2 to $4 \mu \mathrm{c}$. $\mathrm{K}^{\infty}$ were used for injection.

$I^{121}$ labeled serum albumin was obtained from Abbott Laboratories and was prepared for injection of approximately $100 \mu \mathrm{c}$. in $5 \mathrm{ml}$. by dilution with sterile isotonic saline. Three to $4 \%$ of the radioactivity of earlier lots was found to be non-protein bound as determined by 24 to $\mathbf{4 8}$ hour dialysis and by trichloracetic acid precipitation. Seventy-five per cent of the total dialyzable activity appeared outside the membrane within the first hour. In all the arterial studies and in some other cases, prior to injection, dialysis under sterile conditions was performed against saline in beakers changed at frequent intervals. In the cases in which dialysis was not performed prior to injection, necessary corrections as described below were made.

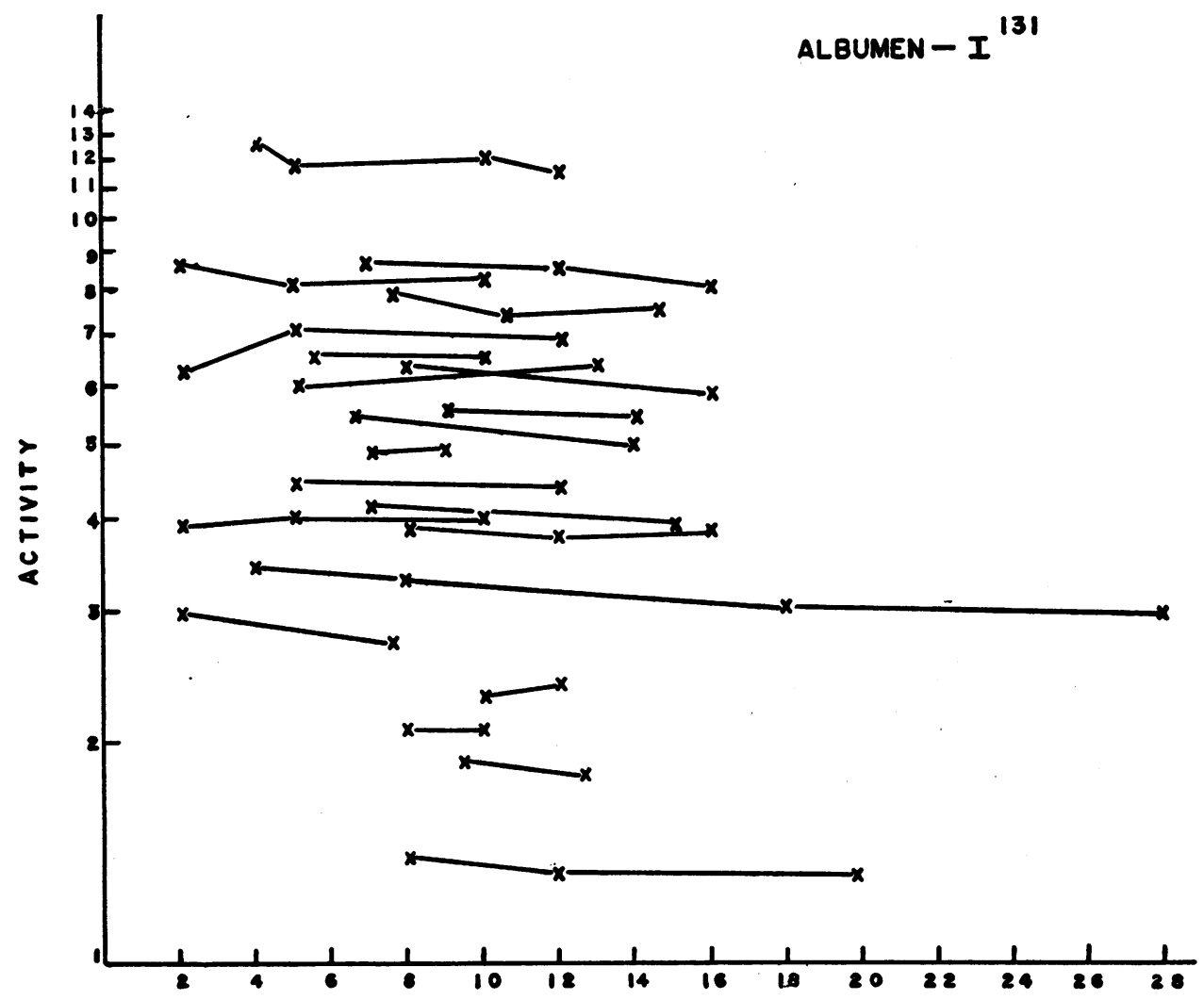

TIME IN MINUTES

Fig. 2. Semilogarithmic Plot-Variation of Venous Concentrations of Im Tagged Albumin with Time

In each case activities are plotted relative to the first point. 


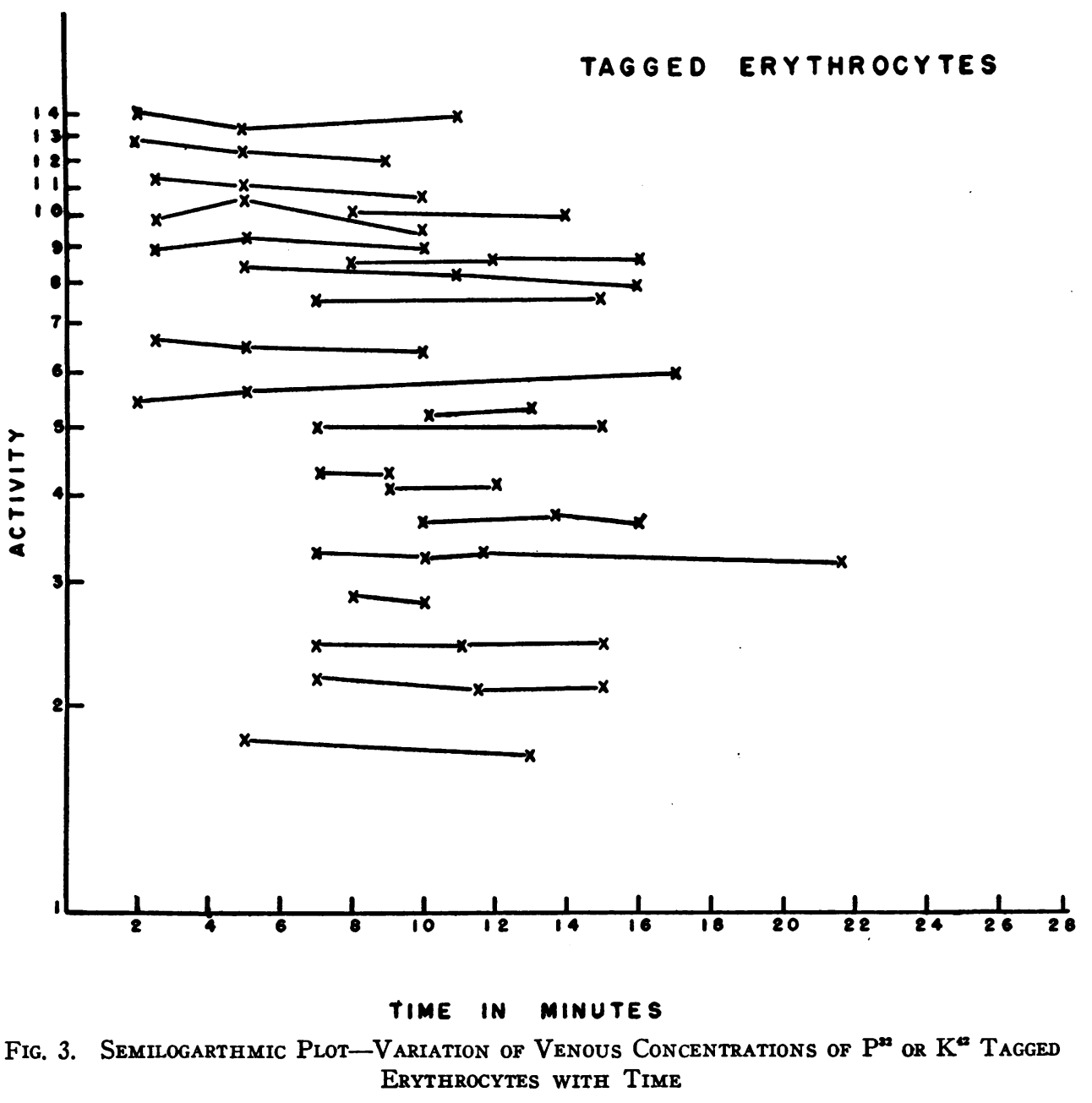

In each case activities are plotted relative to the first point.

Radioactivity of the injected albumin $\mathrm{I}^{121}$ solutions and of the withdrawn whole blood samples was determined by dilution of known volumes to $100 \mathrm{ml}$. in Marinelli beakers placed around an RCL bismuth walled Geiger counter. The sensitivity of this arrangement was 4,500 counts/min./ $\mu c$. $I^{11}$. Since gamma counting was employed, the $I^{121}$ could be assayed in the presence of $P^{32}$. When $K^{2}$ labeled red blood cells were employed, this short lived isotope ( $\mathrm{T} 1 / 2=12.44 \mathrm{hrs}$.) was allowed to decay for a suitable length of time before the $\mathrm{I}^{1 \mathrm{11}}$ was assayed.

Radioactivity of the injected red blood cell suspensions in suitable dilutions and of the withdrawn whole blood specimens was assayed in a horizontal mount containing a thin walled tetramethyl lead filled betagamma counter. When $5 \mathrm{ml}$. liquid samples were placed in a fixed position under the counter, the sensitivity of the arrangement was $6.35 \times 10^{4}$ counts $/ \mathrm{min} . / \mu \mathrm{c}$. $\mathrm{P}^{2 s}$ and $1.63 \times 10^{5}$ counts $/ \mathrm{min} . / \mu \mathrm{c}$. $\mathrm{K}^{12}$. No detectable differences in sensitivity due to unequal absorption by water and whole blood were found for either of the isotopes under the conditions specified.
All counting systems were shielded with 1 inch of lead. A minimum of 5,000 to 10,000 counts was recorded for each specimen. The counting rates of the samples were 20 to 50 times the background count.

Hematocrits were determined in Wintrobe tubes subjected to a maximum R.C.F. of $2,000 \mathrm{~g}$ at the tip for onehalf hour.

For greater accuracy, weighed solutions were injected and the volumes calculated from the weight and measured density of these solutions. For determinations using venous samples, the syringes were weighed empty and with the appropriate solution. These were then rinsed several times with the patient's blood during the injection to insure complete delivery. For the arterial studies, where rapid delivery was desired, the syringe and needle were weighed with the solution to be injected and again after injection without rinsing, care being taken to prevent loss of residual solution within the needle at the time of withdrawal from the vein.

All injections were preceded by the aspiration and reinjection of $10 \mathrm{ml}$. of blood to insure central location of 
the needle in the vein. The syringe was then removed and the tagged cell suspension was injected. After blood sampling from the opposite arm was completed, the albumin solution was then injected and sampling was repeated in a similar fashion at the same time intervals. For arterial samples an indwelling needle fitted with a stylus was inserted into the brachial artery prior to the injection of the tagged material. All blood specimens were taken without stasis in syringes wetted with heparin.

The following formulae were used in calculations :

Total blood volume $=\frac{\text { Total injected activity }}{\text { Activity } / \text { ml. whole blood }}$.

The average of the last two withdrawn samples was used to calculate the activity $/ \mathrm{ml}$. whole blood. The times of withdrawal of specimens for the tagged albumin or the tagged red blood samples were the same. Iodide is distributed within 10 to 15 minutes into a space equal to $20 \%$ of the body weight (32) compared to the usual $5 \%$ space which the plasma occupies. When albumin $I^{151}$ solutions were used without prior dialysis the total injected activity was corrected for by subtracting from it $75 \%$ of the total dialyzable activity $(3-4 \%)$ of that solution. It is clear that even a gross error in this correction factor is unlikely to affect the blood volume determination by more than $1 \%$.

$\mathrm{V}_{\mathrm{o}}=\mathrm{RBC}$ volume

$=$ Total blood volume tared $_{\text {RBC }} \times$ hct. $\times 0.98 .^{2}$

$\mathrm{V}_{\mathrm{p}}=$ Plasma volume

$=$ Total blood volume albumin $\mathrm{I}^{12} \times(1-0.98 \times$ hct. $)$.

Average body hematocrit $=\frac{V_{0}}{V_{0}+V_{p}}$.

\section{RESULTS}

\section{1) Mixing time of erythrocytes and albumin}

To determine the relative rates of mixing of the albumin and the erythrocytes, multiple arterial samples of each were obtained from five subjects over the first seven to 15 minutes following injection, the initial sample being taken at $30 \mathrm{sec}-$ onds. In one subject with congestive heart failure the mixing of the tagged albumin alone was studied. Simultaneous studies show that mixing of the tagged red blood cells and of the tagged albumin is approximately $90 \%$ complete within the first $60-90$ seconds unless circulation is markedly

2 Experiments in this laboratory involving the assay of the relative quantity of albumin labeled with $\mathrm{I}^{12}$ in the red blood cell column of the centrifuge tube as compared with the supernatant plasma have shown that under the conditions of centrifugation specified the hematocrit reading is in error by not more than $2 \%$ (33). Therefore, the correction factor of 0.98 has been applied to the hematocrit readings. impaired by heart failure (Figure 1). The rate of decrease of both tagged cells and the tagged albumin concentrations between one and one and a half minutes and seven to 10 minutes is in general higher than that noted at subsequent times. The possibility seems unlikely that excess early loss of albumin from the intravascular circulation occurred, in view of the similar changes which took place in the tagged red cell concentrations. The relatively rapid early fall in concentration must therefore be ascribed to continued mixing which appears to be virtually complete within five to 10 minutes after injection. The venous concentration curves for the tagged albumin (Figure 2) and for the tagged red blood cells (Figure 3 ) in the remaining subjects also show that the differences between the five to eight and the 12 to 25 minute concentrations are accountable by random variation. Other studies in this laboratory $(34,35)$ have shown that the rate of loss of activity from the circulation of either of these labeled substances is of the order of $1 \%$ or less per quarter hour during the first few hours. Thus for samples drawn at 10 and 15 minutes, extrapolated corrections to zero time are unnecessary.

\section{2) Comparison of blood volume determinations with tagged red blood cells and $I^{131}$ tagged albumin}

The hematocrit values, whole blood volume data and calculated values for red blood cell volume $\left(V_{c}\right)$, plasma volume $\left(V_{p}\right)$, average body hematocrit (av. b. hct.) and the ratio of the average body hematocrit to the peripheral vessel hematocrit ( $\left.\frac{\text { av. b. hct. }}{\text { p. v. hct. }}\right)$ are given in Table I. In every case the blood volume determined by dilution of the tagged albumin was greater than that obtained from the tagged erythrocyte studies. Accordingly, the values for whole blood volume calculated by adding the albumin $I^{131}$ plasma volume $\left(V_{p}\right)$ and the tagged erythrocyte volume $\left(V_{c}\right)$ fall between the two. The average body hematocrit $\left(\frac{V_{c}}{V_{o}+V_{p}}\right)$ is therefore in all cases lower than the hematocrit in the large vessels. The mean value for the ratio of average body hematocrit/peripheral vessel hematocrit is 0.924 with a range from 0.860 to 0.996. 
TABLE I

Summary of blood volume data in 25 studies on 21 subjects

\begin{tabular}{|c|c|c|c|c|c|c|c|c|c|c|}
\hline $\begin{array}{l}\text { Case } \\
\text { No. }\end{array}$ & Diagnosis & Het. & $\begin{array}{l}\text { Corr'd } \\
\text { het. }\end{array}$ & $\begin{array}{c}P^{20} \text { or } \\
K^{* 2} \text { B.V. }\end{array}$ & $\mathbf{V}_{\mathbf{0}}$ & Im B.V. & $\mathbf{V}_{\mathbf{p}}$ & $v_{0}+v_{p}$ & $\frac{\dot{v}_{0}}{v_{0}+v_{p}}$ & Ven. $\frac{\text { Body het. }}{\text { het. corr'd }}$ \\
\hline $\begin{array}{l}1 \\
2 \\
3 \\
4 \\
5 \\
6 a \\
b^{*} \\
7 \\
8 \\
9 a \\
b \\
10 a \\
b^{*} \\
11 \\
12 \\
13 \\
14 \\
15 \\
16 a \\
b \dagger \\
17 \\
18 \\
19 \\
20 \\
21\end{array}$ & $\begin{array}{l}\text { Leukemia } \\
\text { Sarcoidosis } \\
\text { Polycythemia vera } \\
\text { Sarcoidosis } \\
\text { Normal } \\
\text { Polycythemia vera, } \\
\text { ASHD; CHF } \\
\text { Cor pulmonale, CHF } \\
\text { ASHD; CHF } \\
\text { Polycythemia vera } \\
\text { Polycythemia vera } \\
\text { Pernicious anemia } \\
\text { ASHD; CHF } \\
\text { HASHD; CHF } \\
\text { Pulmonary TB. } \\
\text { Pulmonary berrylosis } \\
\text { Laennec's cirrhosis } \\
\text { Laennec's cirrhosis } \\
\text { Splenic vein thrombosis } \\
\text { Laennec's cirrhosis } \\
\text { Normal } \\
\text { Polycythemia vera }\end{array}$ & $\begin{array}{l}36.5 \\
47.1 \\
65.2 \\
51.0 \\
44.5 \\
\\
73.0 \\
34.0 \\
44.0 \\
38.0 \\
69.0 \\
67.0 \\
65.0 \\
43.0 \\
16.5 \\
47.1 \\
45.5 \\
38.2 \\
50.3 \\
40.0 \\
38.0 \\
39.3 \\
37.5 \\
30.0 \\
36.8 \\
61.9\end{array}$ & $\begin{array}{l}35.8 \\
46.2 \\
63.7 \\
50.0 \\
43.6 \\
71.5 \\
33.3 \\
43.1 \\
37.2 \\
67.6 \\
65.6 \\
63.4 \\
42.1 \\
16.2 \\
46.2 \\
44.6 \\
37.2 \\
49.3 \\
39.2 \\
37.2 \\
38.5 \\
36.7 \\
29.4 \\
36.1 \\
60.7\end{array}$ & $\begin{array}{ll}\text { P } & 5,900 \\
\text { P } & 4,400 \\
\text { P } & 4,170 \\
\text { P } & 5,780 \\
\text { P } & 5,120 \\
\text { K } & 6,400 \\
\text { P } & 4,950 \\
K & 6,600 \\
\text { P } & 4,000 \\
K & 6,550 \\
\text { P } & 7,240 \\
K & 4,900 \\
\text { P } & 4,800 \\
\text { P } & 4,660 \\
\text { P } & 4,460 \\
\text { P } & 5,800 \\
\text { P } & 2,650 \\
\text { P } & 4,440 \\
\text { P } & 6,170 \\
\text { P } & 6,295 \\
\text { P } & 5,040 \\
\text { P } & 5,140 \\
\text { P } & 5,950 \\
\text { P } & 4,590 \\
\text { P } & 6,590\end{array}$ & $\begin{array}{l}2,100 \\
2,030 \\
3,000 \\
2,890 \\
2,235 \\
4,575 \\
1,650 \\
2,840 \\
1,490 \\
4,435 \\
4,750 \\
3,100 \\
2,020 \\
750 \\
2,060 \\
2,580 \\
985 \\
2,175 \\
2,415 \\
2,330 \\
1,940 \\
1,880 \\
1,750 \\
1,660 \\
3,990\end{array}$ & $\begin{array}{l}\mathbf{6}, 040 \\
4,935 \\
\mathbf{5}, 330 \\
\mathbf{6 , 0 8 0} \\
\mathbf{5 , 5 5 0} \\
\\
\mathbf{7 , 8 5 0} \\
\mathbf{5 , 9 9 0} \\
\mathbf{7 , 7 0 0} \\
\mathbf{4 , 9 3 0} \\
\mathbf{9 , 3 5 0} \\
\mathbf{8 , 5 7 0} \\
\mathbf{5 , 8 5 0} \\
\mathbf{5 , 8 8 0} \\
\mathbf{4 , 6 7 0} \\
\mathbf{5 , 7 9 0} \\
\mathbf{7 , 0 6 0} \\
\mathbf{3}, 320 \\
4,780 \\
\mathbf{6 , 7 5 0} \\
\mathbf{7 , 1 2 0} \\
\mathbf{5 , 2 3 0} \\
\mathbf{6 , 0 4 0} \\
\mathbf{6 , 9 3 0} \\
\mathbf{4 , 9 5 0} \\
\mathbf{7 , 9 5 0}\end{array}$ & $\begin{array}{l}3,880 \\
2,660 \\
1,950 \\
3,040 \\
3,120 \\
2,240 \\
3,990 \\
4,390 \\
3,090 \\
3,120 \\
2,950 \\
2,140 \\
3,410 \\
3,915 \\
3,120 \\
3,920 \\
2,090 \\
2,420 \\
4,100 \\
4,470 \\
3,210 \\
3,820 \\
4,880 \\
3,160 \\
3,140\end{array}$ & 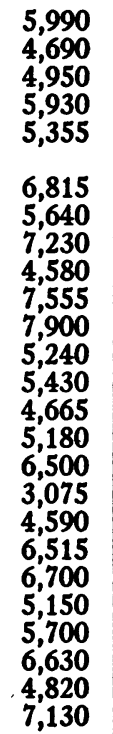 & $\begin{array}{l}35.2 \\
43.3 \\
60.5 \\
48.75 \\
41.6 \\
66.8 \\
29.3 \\
39.3 \\
32.5 \\
58.5 \\
60.1 \\
59.2 \\
37.1 \\
16.1 \\
39.7 \\
39.7 \\
32.1 \\
47.3 \\
37.0 \\
34.9 \\
37.7 \\
32.9 \\
26.4 \\
34.3 \\
56.0\end{array}$ & $\begin{array}{l}.983 \\
.940 \\
.952 \\
.975 \\
.955 \\
.935 \\
.880 \\
.915 \\
.875 \\
.865 \\
.915 \\
.934 \\
.885 \\
.996 \\
.860 \\
.890 \\
.860 \\
.960 \\
.943 \\
.938 \\
.977 \\
.895 \\
.897 \\
.950 \\
.922\end{array}$ \\
\hline
\end{tabular}

* After phlebotomy.

$\uparrow$ After intravenous albumin.

ASHD-Arteriosclerotic heart disease.
CHF-Congestive heart failure.

HASHD-Hypertensive and arteriosclerotic heart disease.

\section{3) One-half hour urinary radioactivity}

When dialyzed albumin was used, the one-half hour urine specimens contained less than $0.1 \%$ of the injected activity. When undialyzed solutions containing $3-4 \%$ non-protein bound activity were injected, less than $0.25 \%$ of the injected activity was excreted in the urine during the half hour period following injection. Previous studies have shown that $5-10 \%$ of injected $\mathrm{KI}^{131}$ appears in the urine during this time (32).

\section{DISCUSSION}

The relationship between the plasma/erythrocyte ratios in large and small vessels has been a point of considerable dispute. An average body hematocrit lower than the peripheral vessel hematocrit has been interpreted as indicating that the plasma/red cell ratio in minute vessels throughout the body is greater than the ratio found in the large peripheral vessels which are readily available for sampling. A principal source of disagreement among previous workers arises in the method of estimating plasma volume by assay of plasma alone for dye content or radioactivity and of red blood cell volume by the assay of whole blood or packed erythrocytes. The accuracy of the hematocrit reading then becomes an important factor in the determination of the ratio of average body hematocrit to peripheral vessel hematocrit. Estimations of the error of the hematocrit have ranged from $-5 \%$ to $+8.5 \%$ (33). Thus, identical data for erythrocyte and plasma dilution may be obtained by different investigators, but, owing to the application of different correction factors for the same hematocrit, or of an identical correction for hematocrits with different errors, divergent interpretations are expressed. In most reports, the conditions of centrifugation under which the hematocrit readings were obtained are not given. It has been shown that the error of the hematocrit obtained in tubes spun for $\mathbf{3 0}$ minutes at $\mathbf{5 0 0}$ $\mathrm{g}$ is $8.5 \%$ but at $2,000 \mathrm{~g}$ is not more than $2 \%$ (33). From these considerations, it appears likely that discrepancies in previously reported studies may at times be related to calculations involved in the determination of total blood volume from the dye 
plasma volume and the hematocrit rather than to real differences in the dilution factors.

In the present study this difficulty has been circumvented by assaying whole blood for tagged red cell and tagged albumin activity alike. Hence, the correction applied to the hematocrit reading is of negligible importance in evaluating the average body hematocrit/peripheral vessel hematocrit ratio because such a correction affects both to almost the same extent. In the present study this ratio was always less than one. However, its mean value is not as low as that obtained by some other workers using Evans blue and tagged cell methods, which again raises the possibility that the dye method leads to overestimation of plasma volume. Even if it is accepted that, when injected in proper concentration, most of the dye becomes bound to serum albumin, early loss from the intravascular circulation before complete binding has occurred cannot be excluded. The studies of Barnes, Loutit, and Reeve (36) in vitro have shown that the binding is not complete until 40 to 50 seconds at body temperature. The circulation time to the lungs is of the order of four to eight seconds and it is probable that some unbound fraction still remains at that time to pass through the pulmonary capillaries, or that the vascular endothelium may compete with the serum albumin for the binding of the dye. Meneely, Wells, and Hahn (17) showed that, following injection of dye labeled plasma from a donor, the "mixing phase" was less marked than that following the administration of dye alone. The staining of veins subjected to numerous injections of the dye is obvious even through the skin (37). Tagged albu$\mathrm{min}$ is free of these objections, and would seem to be more satisfactory for estimation of plasma volume than a dye, the suitability of which depends upon its becoming bound to albumin.

It has been stated that the time for mixing of plasma soluble substances and red blood cells is perceptibly different, the latter being the more rapid (15). No consistent differences were observed after 30 seconds in the five cases studied here. In the case of both, mixing to the extent of about $90 \%$ of the equilibrium value took place within one to one and a half minutes but the attainment of apparent equilibrium took five to 10 minutes. This suggests that most of the circulat- ing blood is in very free intercommunication but that there are some depots to the extent of 5 to $10 \%$ of the total blood volume which are less readily penetrated. The situation in shock has not been investigated. In the case of circulatory impairment, as in heart failure, the earlier phase of mixing may be retarded but equilibrium was fairly well established in less than 10 minutes in the one case studied. Since, after the initial mixing period of five to 10 minutes, the rate of fall in the concentration of the tagged red blood cells or albumin is less than $1 \%$ per quarter hour, samples drawn between 10 and 20 minutes after injection do not require an extrapolation correction.

\section{SUM MARY}

1. Simultaneous blood volume determinations utilizing albumin tagged with $\mathrm{I}^{131}$ and erythrocytes tagged with $\mathrm{P}^{32}$ or $\mathrm{K}^{42}$ have been performed in 25 tests on 21 subjects. In every instance, the whole blood volume evaluated by the tagged albumin dilution was greater than that derived from the dilution of the tagged erythrocytes. The average body hematocrit/peripheral vessel hematocrit ranged from 0.860 to 0.996 with a mean value of 0.924 . Since whole blood samples were assayed, these ratios did not depend on the accuracy of the observed hematocrit reading.

2. Arterial mixing curves revealed that apparent equilibrium may not be attained until five to 10 minutes after injection although the concentrations at one to one and a half minutes are only approximately $10 \%$ above the equilibrium values. There is no essential difference in the mixing times of tagged albumin and erythrocytes.

3. Albumin tagged with $\mathrm{I}^{\mathbf{1 3 1}}$ is a satisfactory material for the estimation of circulating plasma volume. Owing to the difference between average body hematocrit and peripheral vessel hematocrit the accurate evaluation of whole blood volume requires independent determinations of plasma and red blood cell volumes.

\section{ACKNOWLEDGMENTS}

The authors gratefully acknowledge the technical assistance of Katharina Newerly and Oscar Vazquez and the secretarial assistance of Frieda Steiner and Florence Cavanagh. Thanks are also due to Dr. Daniel Stone and Dr. Arthur Schwartz of the Medical Service for their 
aid in obtaining the arterial blood specimens, and to Sidney Shapiro, Paul Newman and George Davis of the Medical Illustration Department.

\section{REFERENCES}

1. Haldane, J., and Smith, J. L., The mass and oxygen capacity of the blood in man. J. Physiol., 1900, 25, 331.

2. Barnes, D. W. H., Loutit, J. F., and Reeve, E. B., A comparison of estimates of circulating red blood cell volume given by Ashby marked red cell method and T-1824 haematocrit method in man. Clin. Sc., 1948, 7, 135.

3. Ashby, W., The determination of the length of life of transfused blood corpuscles in man. J. Exper. Med., 1919, 29, 267.

4. Hahn, P. F., Balfour, W. M., Ross, J. F., Bale, W. F., and Whipple, G. H., Red cell volume circulating and total as determined by radio iron. Science, 1941, 93, 87.

5. Gibson, J. G., 2nd, Peacock, W. C., Seligman, A. M., and Sack, T., Circulating red cell volume measured simultaneously by the radioactive iron and dye methods. J. Clin. Invest., 1946, 25, 838.

6. Gray, S. J., and Sterling, K., Determination of circulating red cell volume by radioactive chromium. Science, 1950, 112, 179.

7. Hahn, L., and Hevesy, G., A method of blood volume determination. Acta physiol. Scandinav., 1940, 1, 3.

8. Yalow, R. S., and Berson, S. A., The use of $\mathrm{K}^{42}$-tagged erythrocytes in blood volume determinations. Science, 1951, 114, 14.

9. Gibson, J. G., 2nd, and Evans, W. A., Jr., Clinical studies of the blood volume. I. Clinical application of a method employing the azo dye "Evans Blue" and the spectrophotometer. J. Clin. Invest., 1937, 16, 301.

10. Rawson, R., Binding of T-1824 and structurally related azo dyes by the plasma proteins. Am. J. Physiol., 1943, 138, 708.

11. Krieger, H., Storaasli, J. P., Friedell, H. L., and Holden, W. D., A comparative study of blood volume in dogs. Proc. Soc. Exper. Biol. \& Med., 1948, 68, 511.

12 Storaasli, J. P., Krieger, H., Friedell, H. L., and Holden, W. D., The use of radioactive iodinated plasma protein in the study of blood volume. Surg., Gynec. \& Obst., 1950, 91, 458.

13. Crispell, K. R., Porter, B., and Nieset, R. T., Studies of plasma volume using human serum albumin tagged with radioactive iodine. J. Clin. Invest., 1950, 29, 513.

14. Smith, H. P., Arnold, H. R., and Whipple, G. H., Blood volume studies. VII. Comparative values of Welcker, carbon monoxide and dye methods for blood volume determinations; accurate estimation of absolute blood volume. Am. J. Physiol., 1921, 56, 336.

15. Hahn, P. F., Ross, J. F., Bale, W. F., Balfour, W. M., and Whipple, G. H., Red cell and plasma volumes (circulating and total) as determined by radio iron and by dye. J. Exper. Med., 1942, 75, 221.

16. Hevesy, G., Köster, K. H., Sørensen, G., Warburg, E., and Zerahn, K., The red corpuscle content of the circulating blood as determined by labelling the erythrocytes with radio-phosphorus. Acta. med. Scandinav., 1943-44, 116, 561.

17. Meneely, G. R., Wells, E. B., and Hahn, P. F., Application of the radioactive cell method for determination of blood volume in humans. Am. J. Physiol., 1947, 148, 531.

18. Nachman, H. M., James, G. W., III, Moore, J. W., and Evans, E. I., A comparative study of red cell volumes in human subjects with radioactive phosphorus tagged red cells and T-1824 dye. J. Clin. Invest., 1950, 29, 258.

19. Stead, E. A., Jr., and Ebert, R. V., Relationship of plasma volume and the cell plasma ratio to the total red cell volume. Am. J. Physiol., 1941, 132, 411.

20. Gregersen, M. I., A practical method for the determination of blood volume with the dye T-1824. A survey of the present basis of the dye method and its clinical applications. J. Lab. \& Clin. Med., 1944, 29, 1266.

21. Noble, R. P., and Gregersen, M. I., Blood volume in clinical shock. II. The extent and cause of blood volume reduction in traumatic, hemorrhagic and burn shock. J. Clin. Invest., 1946, 25, 172.

22. Hopper, J., Jr., Tabor, H., and Winkler, A. W., Simultaneous measurements of the blood volume in man and dogs by means of Evans blue dye, T-1824, and by means of carbon monoxide. I. Normal subjects. J. Clin. Invest., 1944, 23, 628.

23. Nickerson, J. L., Sharpe, L. M., Root, W. S., Fleming, T. C., and Gregersen, M. I., Simultaneous blood volume determinations in dogs with dye ( $T$-1824), carbon monoxide and radioactive iron $\mathrm{Fe}^{\mathrm{ss}}$. Federation Proc., 1950, 9, 94.

24. Mayerson, H. S., Lyons, C., Parson, W., Nieset, R. T., and Trautman, W. V., Jr., Comparison of results of measurement of red blood cell volume by direct and indirect technics. Am. J. Physiol., 1948, 155, 232.

25. Chapin, M. A., and Ross, J. F., Determination of true cell volume by dye dilution, by protein dilution and with radioactive iron. Error of the centrifuge hematocrit. Am. J. Physiol., 1942, 136, 447.

26. Wasserman, L. R., Yoh, T., and Rashkoff, I. A., Blood volume determination: comparison of $\mathrm{T}-1824$ and $\mathrm{P}^{23}$ labeled red cell methods. J. Lab. \& Clin. Med., 1951, 37, 342.

27. Scott, H. W., Elliott, S. R., II, and Clay, R. C., Blood volume in congenital cyanotic heart disease; simul- 
taneous measurements with Evans blue and radioactive phosphorus. Bull. Johns Hopkins Hosp., 1951, 89, 121.

28. Ferrebee, J. W., Leigh, O. C., and Berliner, R. W., Passage of the blue dye, T-1824, from the blood stream into the lymph. Proc. Soc. Exper. Biol. \& Med., 1941, 46, 549.

29. Lawson, H. C., Overbey, D. T., Moore, J. C., and Shadle, O. W., Mixing of cells, plasma and dye T-1824 in the cardiovascular system of barbitalized dogs. Am. J. Physiol., 1947, 151, 282.

30. Peters, J. P., The role of sodium in the production of edema. New England J. Med., 1948, 239, 353.

31. Lawson, H. C., Overbey, D. T., Shadle, O. W., and Moore, J. C., Effect of plasma injection on dye and cell content of arterial blood. Am. J. Physiol., 1947, 151, 303.

32. Berson, S. A., Yalow, R. S., Sorrentino, J., and Roswit, B., The determination of thyroidal and renal plasma I $I^{21}$ clearance rates as a routine diagnostic test of thyroid dysfunction. J. Clin. Invest., 1952, 31, 141.
33. Vazquez, O. N., Newerly, K., Yalow, R. S., and Berson, S. A., Determination of trapped plasma in the centrifuged erythrocyte volume of normal human blood with radioiodinated ( $\left.I^{212}\right)$ human serum albumin and radiosodium $\left(\mathrm{Na}^{2 \mathrm{t}}\right)$. J. Lab. \& Clin. Med., 1952, 39, 595.

34. Berson, S. A., Yalow, R. S., Azulay, A., Schreiber, S., and Roswit, B., The biological decay curve of $P^{* 0}$ tagged erythrocytes. Application to the study of acute changes in blood volume. J. Clin. Invest., 1952, 31, 581.

35. Berson, S. A., Yalow, R. S., and Post, J., The intravascular time concentration curve of albumin $I^{121}$. Studies of albumin distribution and metabolism. In preparation.

36. Barnes, D. W. H., Loutit, J. F., and Reeve, E. B., Observations on the estimate of the circulating red blood cell volume in man given by T-1824 and the haematocrit, with special reference to uncorrected dye loss from the circulation. Clin. Sc., 1948, 7, 155.

37. Personal observation. 